Article

\title{
Houses and Daily Life in Islamic Portugal (12th-13th Century): Mértola in the Context of Gharb
}

\author{
Santiago Macias \\ Câmara Municipal de Lisboa, Rua do Machadinho 20, 1249-150 Lisboa, Portugal; \\ santiagomacias1963@gmail.com; Tel.: +351-964003729
}

Received: 31 July 2018; Accepted: 1 November 2018; Published: 6 November 2018

\begin{abstract}
This is an overview of the houses in southern Portugal, at the final stages of the Islamic period, using Mértola as the case study. Recent archaeological works, performed in different places, give us information on the houses' organization, as well on the daily life of the population. Alimentary habits have been disclosed through a series of analyses.
\end{abstract}

Keywords: Portugal; archaeology; houses; Islamic period

\section{Introduction}

The last three decades have been extremely fruitful in presenting information regarding the living situation in southern Portugal during the Islamic Period. Only during the 1990s was this information disclosed. Mértola and Silves were the first two locations to provide us with consistent and reliable information. In the first location, a neighbourhood of the end of the Islamic period was identified. In the second, a palatine structure, much more complex and sophisticated, was found. The following decades were defined by an intense urban archaeological activity, that yielded a rather substantial number of dwellings. Mértola and Silves are still the most significant examples for the study of urban housing in the Islamic Period. Nonetheless, other relevant places have been added to the list, such as Paderne, Tavira, Lisboa, Moura, etc. This essay will explore the characteristics of the Islamic neighborhoods in southern Portugal. To better illustrate this, the essay will use the Islamic neighbourhood of Mértola as a case study.

\section{Urban Structures}

Placed on important inter-fluvial locations, controlling significant waterways or simply occupying exceptional strategic points, southern Portuguese cities retained their importance throughout the Medieval period, or more often than not, gradually became more influential. Their dynamics, inherited from the ancient world, remained unaltered throughout both late antiquity and the first phase of Islamisization. Some examples of these cities are Lisbon, Santarem, Coimbra, Mértola and Silves.

Each urban centre traditionally retained under its control a territory. The topography of these centres underwent, in most cases, very few changes during several centuries, to the point that their boundaries match with county borders today. Moreover, it can be said that the topography of the Islamisized cities of the Gharbe overlaid the former urbes of the end of the Roman empire (Torres 1992, pp. 394-97). Nonetheless, the characterization of Muslim urbanism as irrational and labyrinthine when compared to the classical and balanced Christian urbanism prompt us to make some brief considerations.

1. The orthogonality in urban schemes is not related to whether the city is Christian or Muslim. It is connected to the dependence on an authoritarian power and its capacity to order or impose certain construction programs. Geometric urban layouts, designed according to pre-established 
architectural schemes, abound in the Medieval Muslim world. That urban geometry is noticeable in the concentric plan of Baghdad, when it was the capital of the Abassid Empire, or Madinat az-Zahra, an orthogonal palatine complex in the classical fashion, fruit of the intervention of a caliphal power with hegemonic pretensions, constructed from scratch and for the exclusive use of the Cordoban caliphal court. Its layout is rigorously quadrangular, and its urbanism is rationally outlined with areas perfectly delineated in accordance with the function of each space (Vallejo Triano 2013, p. 91). There are many other examples such as the outskirts neighbourhood of El Forti, in Denia (Alicante) (Gisbert Santonja et al. 1992, pp. 27, 42 and Figure 7) and the interior of the abandoned city of Saltés (Huelva) (Bedia and Bazzana 1994, p. 625), an urban arrangement that was conceived from scratch and whose plan, street layout and sanitation system were all put in place before the building of the houses.

2. On the other hand, it is fitting to remember that the Mediterranean city (and, naturally, the Andalusian city) is designed, first of all, by a rigid classical anti-urbanism. If, in the planning schemes of cities organized in the Alexandrian or Roman fashion, an adopted pattern indicates the presence of a rationalizing power, the mercantile urbe, catalyst of the Mediterranean polis, can be compared to a living body in which all the equilibriums are organic and functional. The old frameworks of the port cities of Génova or Marselha, having in common the fact of never having been Islamicized, possess however an urbanism of an inorganic character, easily categorizable as "Islamic". In the Mediterranean cities, regardless of being Christian or Muslim, adaptation to the lie of the land was the rule. With the area of power concentrated in the acropolis, the city is organized in an autonomous way following the logic of a conglomerate of neighbourhoods interwoven with vast family clans.

3. Most of the cities of Gharb al-Andalus, following a millennial Mediterranean tradition, were organized in the following way: always close to an enclosure and, in the most strategically defendable place, possessing an alcácer (qasr), a cell of eminently military functions, along with the alcáçova (qasaba). This area, nearly always overlapping with the most important spaces of the Roman city, formed a true world apart, closed in on itself. At the side of this nucleus of power grew the city (medina-a name only applicable to the more important cities), normally walled with battlements. Within these walls, it was possible to find the markets, the baths, and the religious spaces etc. and the houses of the local merchant artisans, market-gardeners and peasants. Frequently, in the most important settlements, the city would expand outside its walls, thus creating the outskirts.

Nevertheless, the most visible features of these cities are the battlements. Those that remain in Portugal are nearly all from the Almohad period and date from the second half of the 12th century. They were constructed during a period when the military pressure of the Christian Reconquista threatened the cities of the south and, thus, it was necessary to protect the populations from a near permanent menace. The Almohad fortifications in southern Portugal were constructed in taipa (compressed clay mixed with chalk), a method used until just recently in traditional architecture in the south of Portugal. Sometimes, a matrix was painted on the facade to imitate the stone blocks of the classical fortifications: Alcácer do Sal (Pereira 2000, p. 125; Leitão 2015, p. 29), Moura (Macias et al. 2016, p. 44), Paderne (Catarino 2005, p. 141) and Salir (Catarino 2005, p. 140) are an example of such.

The cemeteries (maqbaras) were situated outside the walls, and always far from any contact with the living, normally re-occupying earlier funereal spaces. In certain cases, the city was organized in two differentiated and autonomous poles, as happened at Santarém and Alcácer do Sal. In others, as in Lisbon and Coimbra, they were united in a single urban mass (Torres 1992, p. 397).

\section{Habitational Structures}

In the absence of spectacular palaces or great monumental complexes, it is only now, through the process of archaeological intervention, that this Islamic world is starting to be discovered. 
A look at traditional housing in the north and south of the country shows us immediately that the southern construction models (taipa, adobe, caniço) coincide with those of the former Gharb al-Andalus. In the regions to the south, the gentleness of the climate contributed in such a decisive way so that a significant part of human activity was carried out in the fresh air, not only in the suqs and in the city squares, but also at home, where the open interior patio had, and continues to have, a distinguished role.

In the Gharb, only Silves (in relation to which there are literary references to a palatine zone, like in the famous poem of al-Mutamid-Coelho 1975, pp. 300-2) and Lisbon (with a royal palace that survived until the 16th century-de Matos 1999, p. 20) would have possessed important alcáçovas (Gomes and Gaspar 2002, pp. 401-3).

In Mértola (Figures 1 and 2), excavations have been carried out over the past 10 years in a neighbourhood in which have been identified, until now, 16 houses (Palma et al. 2018). It is a habitational complex dateable to the second half of the 12th century which overlies former Byzantine structures (Macias 2006). The archaeological operation has, to this date, uncovered a well-organized network of streets and houses (Figures 3 and 4), where some planning is visible, in particular when we notice the presence of sanitation systems in all of the houses of the neighbourhood.

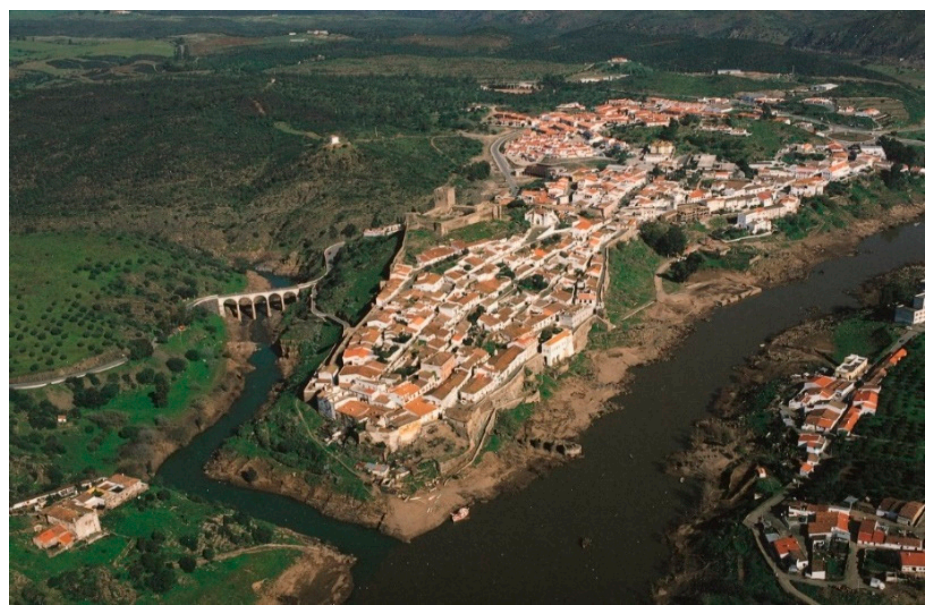

Figure 1. Mértola. Photo took by author.

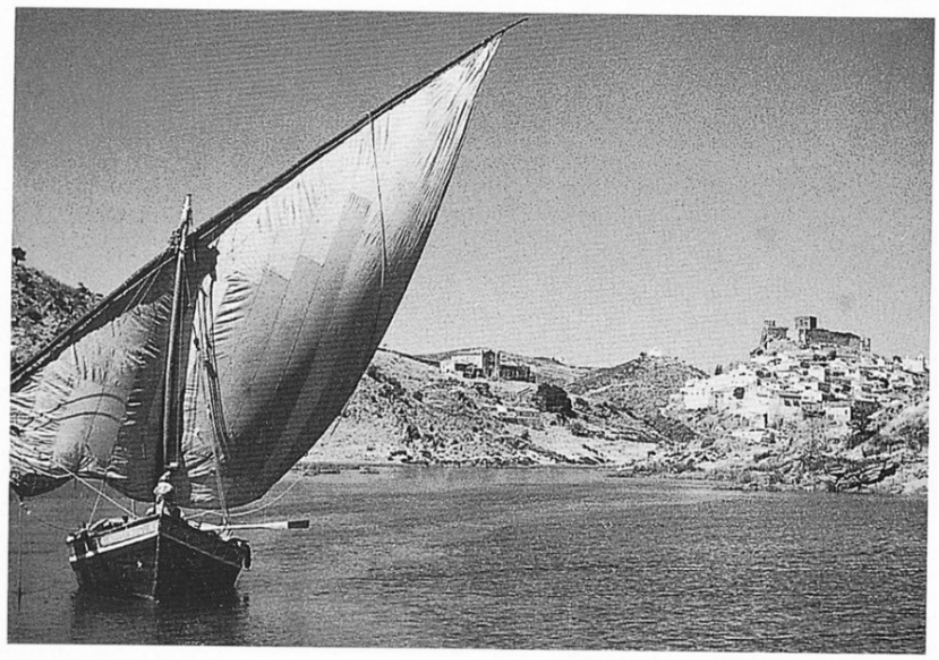

Figure 2. Mértola (c. 1930). Photo owned by the author. 


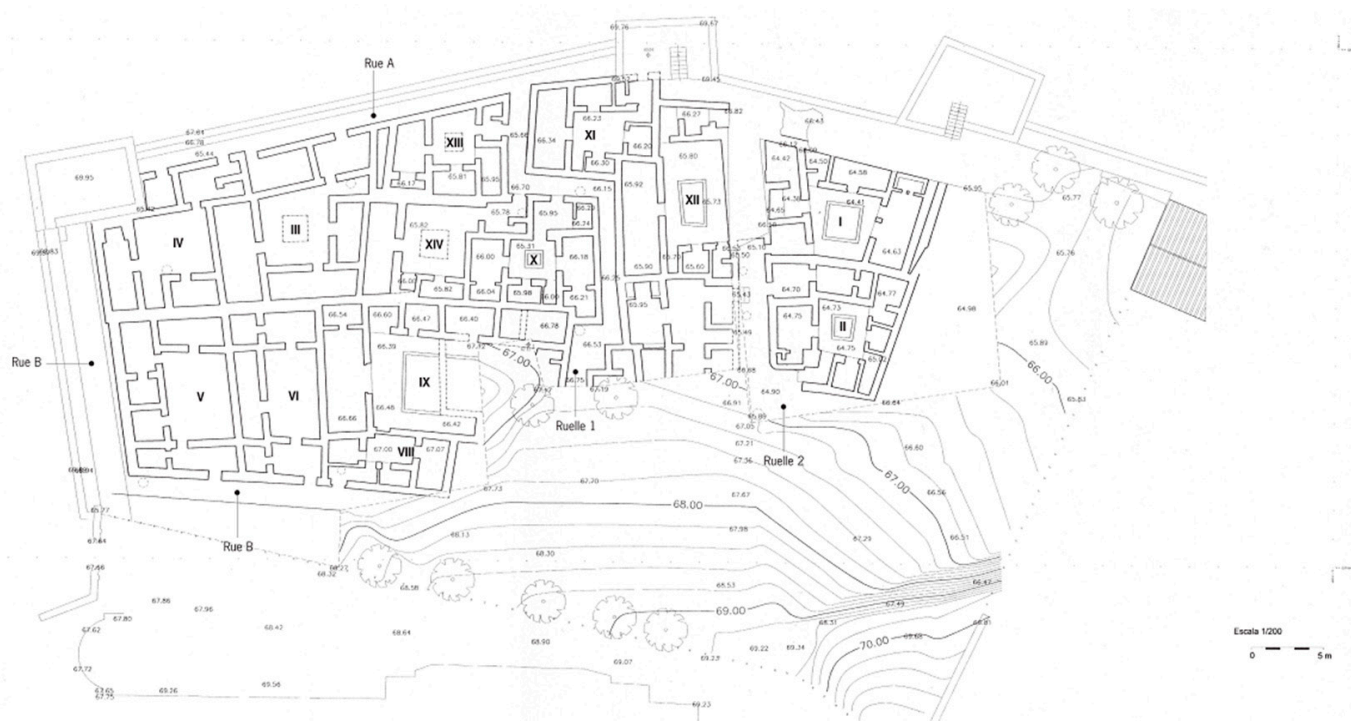

Figure 3. Mértola-Islamic quarter plan. Plan by the author.

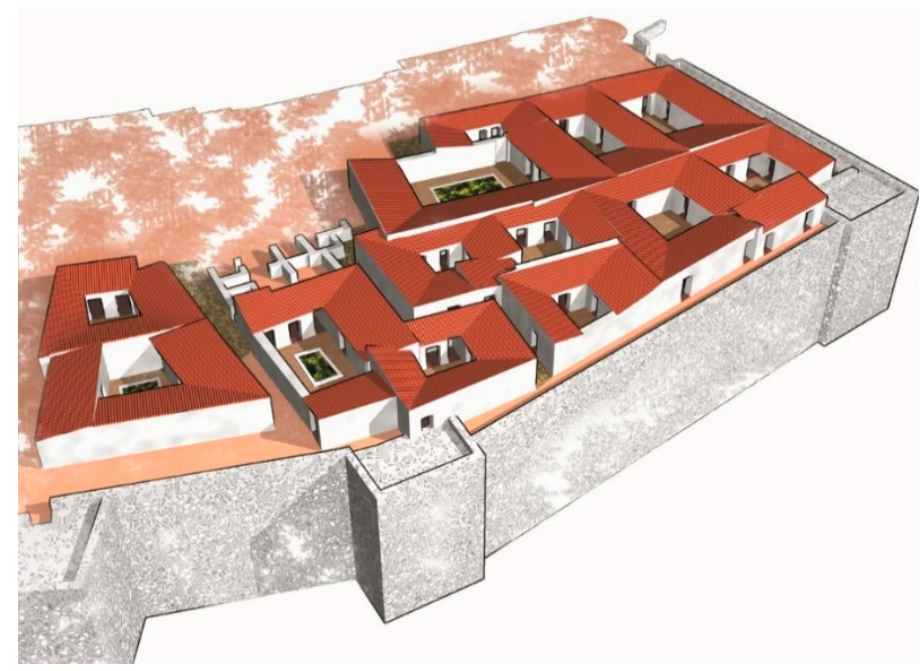

Figure 4. Mértola-Islamic quarter reconstitution. Reconstitution by the author.

These houses are structured around a central patio that occupies about a quarter of the total area of the dwelling (which is around $70 / 80 \mathrm{~m}^{2}$ in the case of Mértola-Macias 2006, p. 387-see plan in Figure 5). The entrance to the house is made through an atrium, which communicates directly with the patio. This is the applicable general rule, which can often be seen in the many archaeological sites of the Gharb. The areas of the dwellings can vary, but in general terms, the layout remains the same. This is perceptible in Paderne (Inácio and Catarino 2009, p. 616), Silve's castle (Gomes 2009, p. 484) and Silve's suburbs (Gonçalves 2008b, pp. 98-101), and in Tavira (Cavaco 2011, p. 86 and XVI-Figure 7). Around this patio are distributed the compartments/rooms, and it is noticeable that each dwelling is organized in the following way:

\subsection{Entrance through an Atrium}

Frequently, the entrance (Figure 6) is given some importance, normally through the placement of architectonic fragments from the Roman era (columns, for example) serving as doorsteps (Macias 2006, p. 392). 


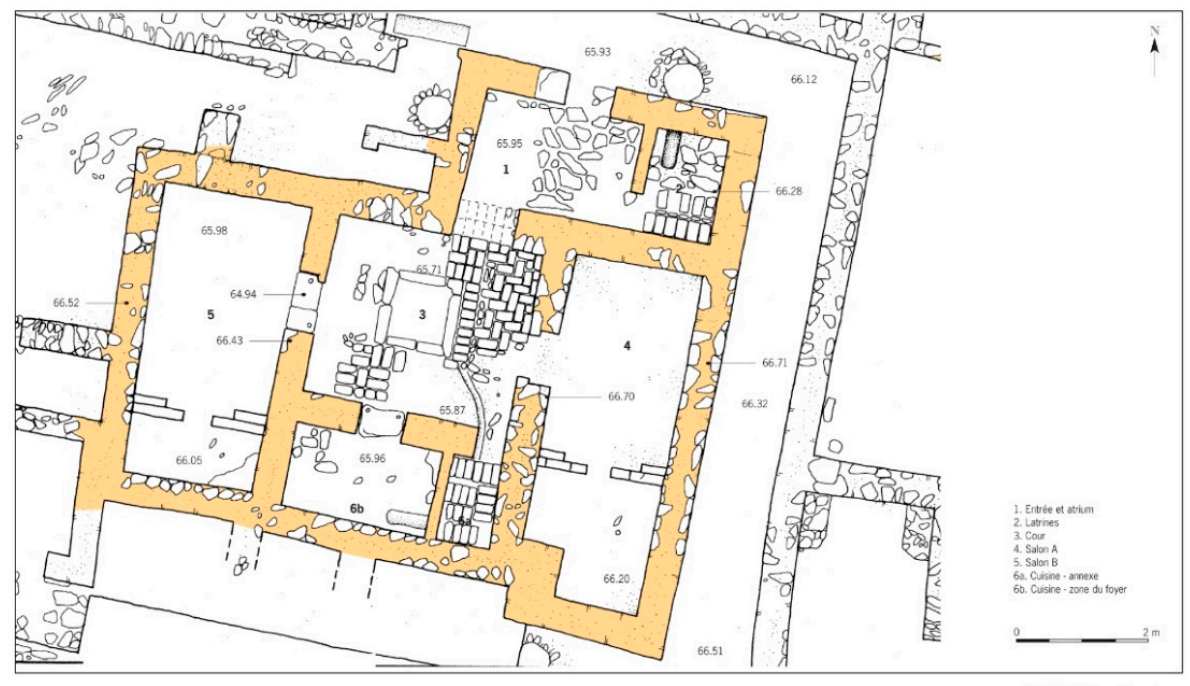

Figure 5. Mértola—house n. 10 (plan). Plan by the author.

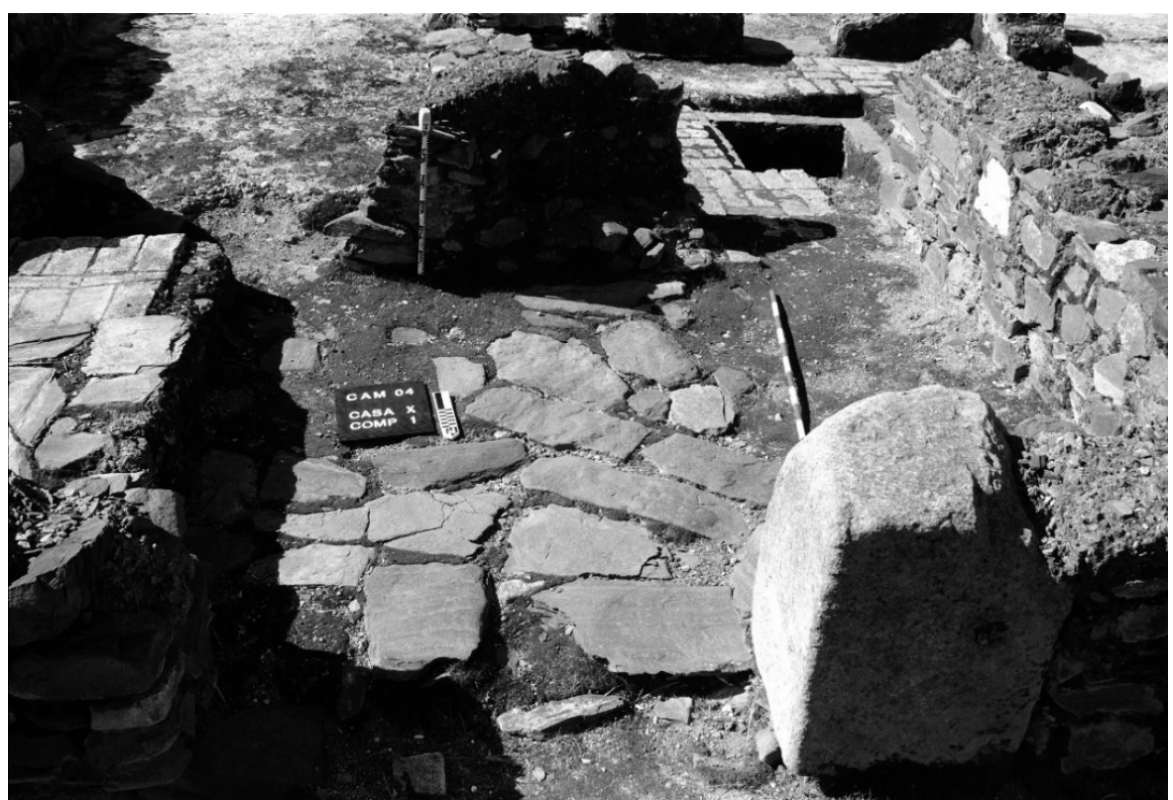

Figure 6. Mértola-house n. 10 (entrance). Photo took by author.

\subsection{Uncovered Central Patio}

The patio occupied about a quarter of the area of the house and, bearing in mind the dry climate of the region, it is probable that a large part of daily activities, for example, meal prepping, took place in this area. Generally speaking, patios are very intimate sections of the house (Figure 7). In Silves' suburbs, however, some houses have patios that connect directly to the street (Gonçalves 2008a, pp. 97-98).

\subsection{Principal Room with Mortar Floor, Painted with Red Ochre, with a Small Recess/Alcove in the Top}

This room was undoubtedly the place designated for family gatherings, eating meals and sleeping. The couple that owned the house would sleep in the recess (alcova). The recess is an elevated area, that is meant to have a bed-frame (Figure 8), something very typical of archaeological sites of the Gharb (Bazzana 2005, pp. 120-21). 


\subsection{Smaller Room of Multiple Functions}

Here it is assumed that some food supplies were kept. Not only do the other areas seem to be rather specific in their function, but also archaeological evidence points towards a multi-purpose room (Macias 1996).

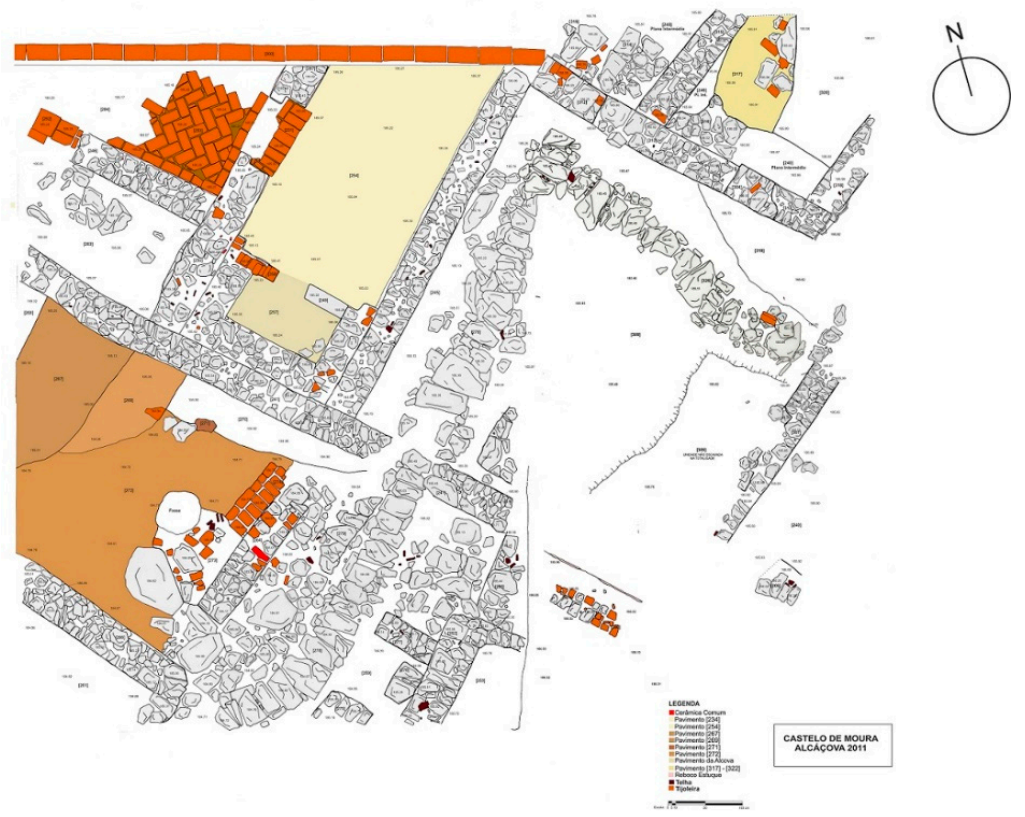

Figure 7. Moura-remains of the patio, among 17th-century structures.

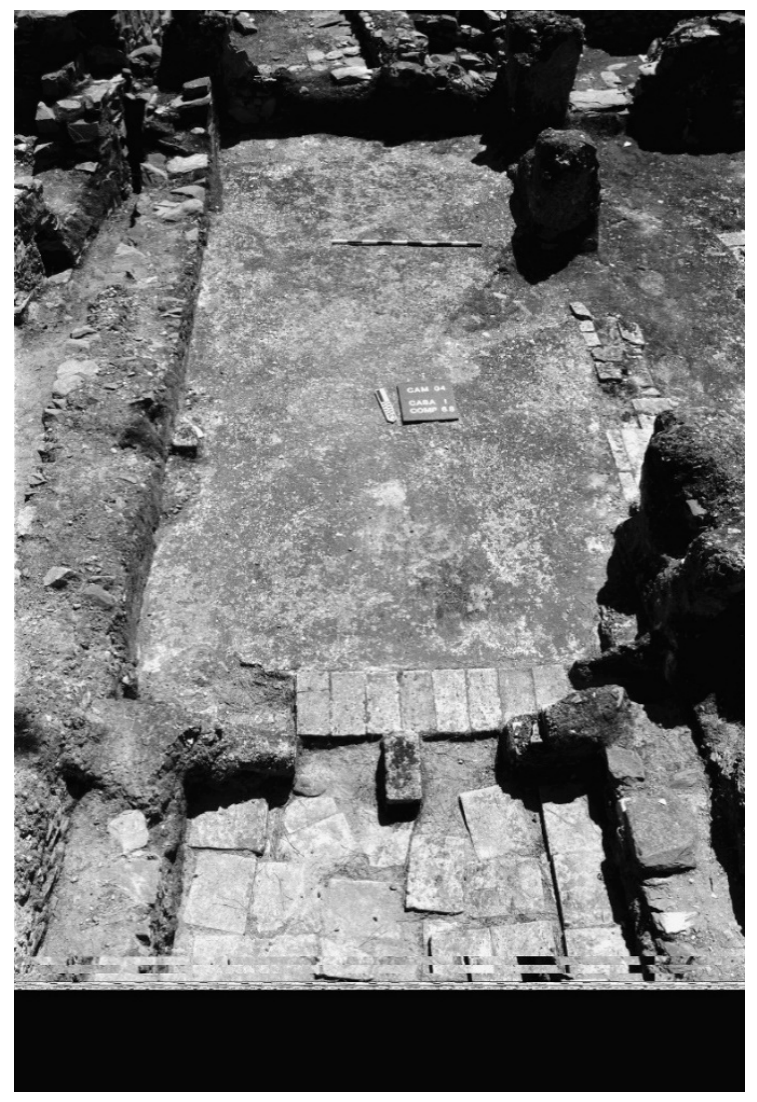

Figure 8. Mértola-house n. 1 (main room). Photo took by author. 


\subsection{Kitchen Divided into Two Areas}

There was an exterior compartment for keeping water pitchers (some were found in this space), and for keeping food supplies, and an interior space with a fireplace (Figures 9-11). The hearths were, as a rule, excavated in the earth and delimited with stones, a solution that is maintained until the present day in archaic zones of the south (Macias 1996, pp. 104-5) (Figure 12). This division of kitchen space is characteristic of Islamic Mértola.

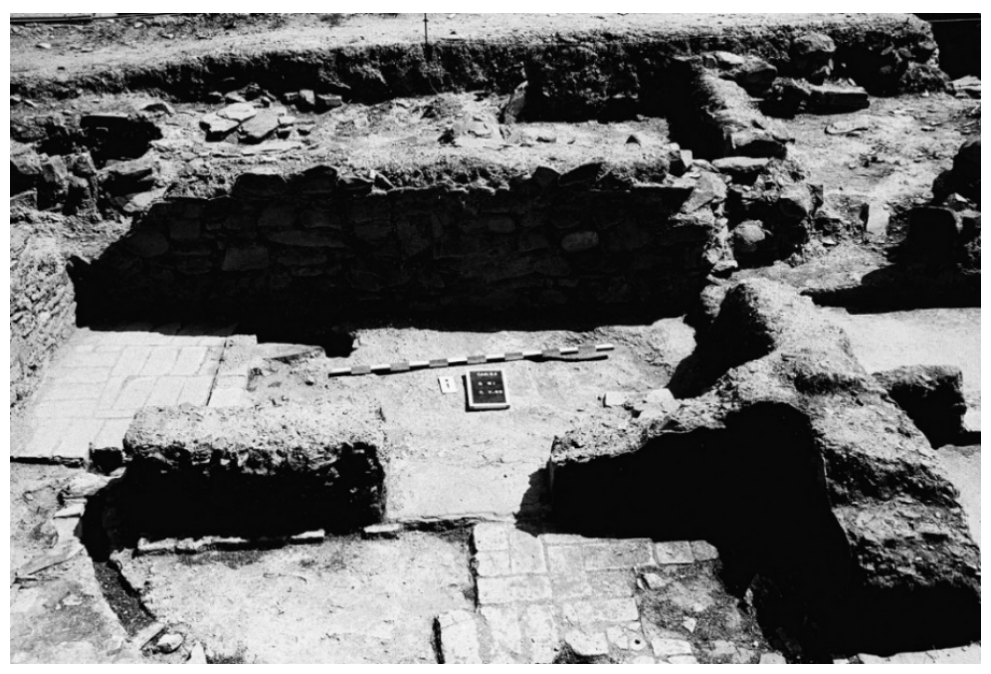

Figure 9. Mértola-house n. 10 (kitchen). Photo took by author.

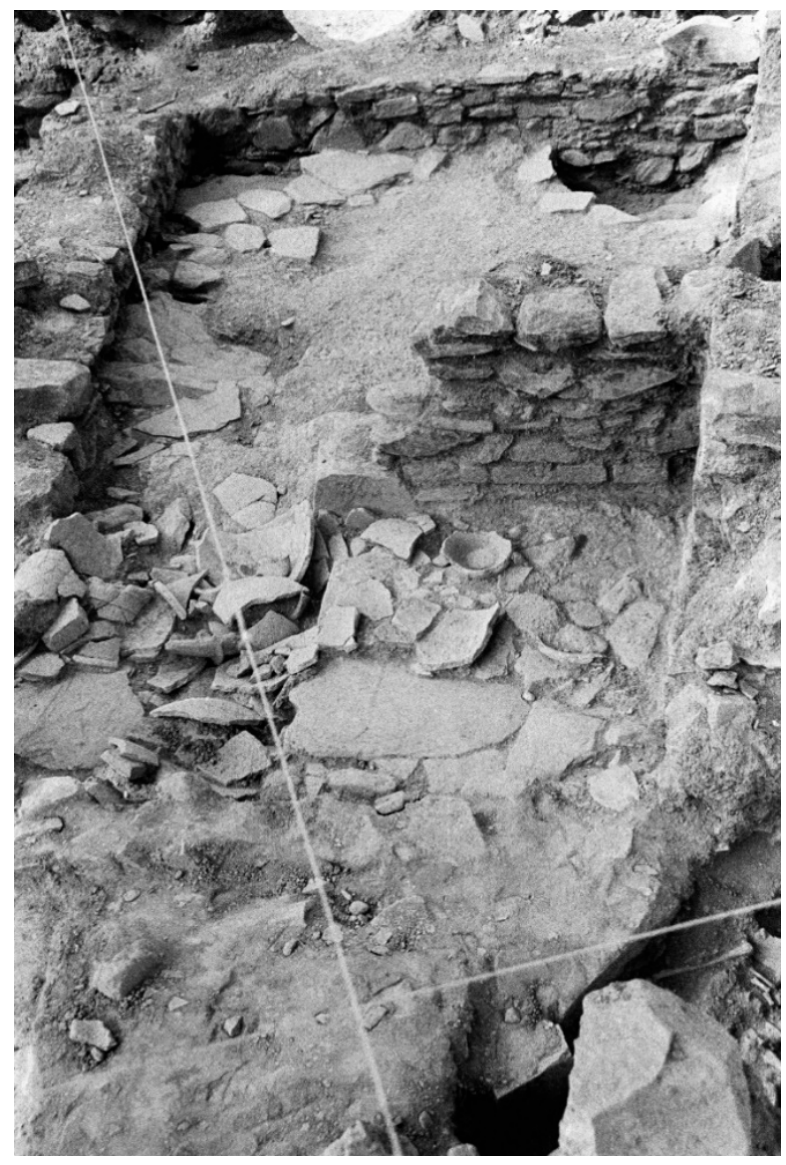

Figure 10. Mértola-house n. 2 (kitchen). Photo took by author. 


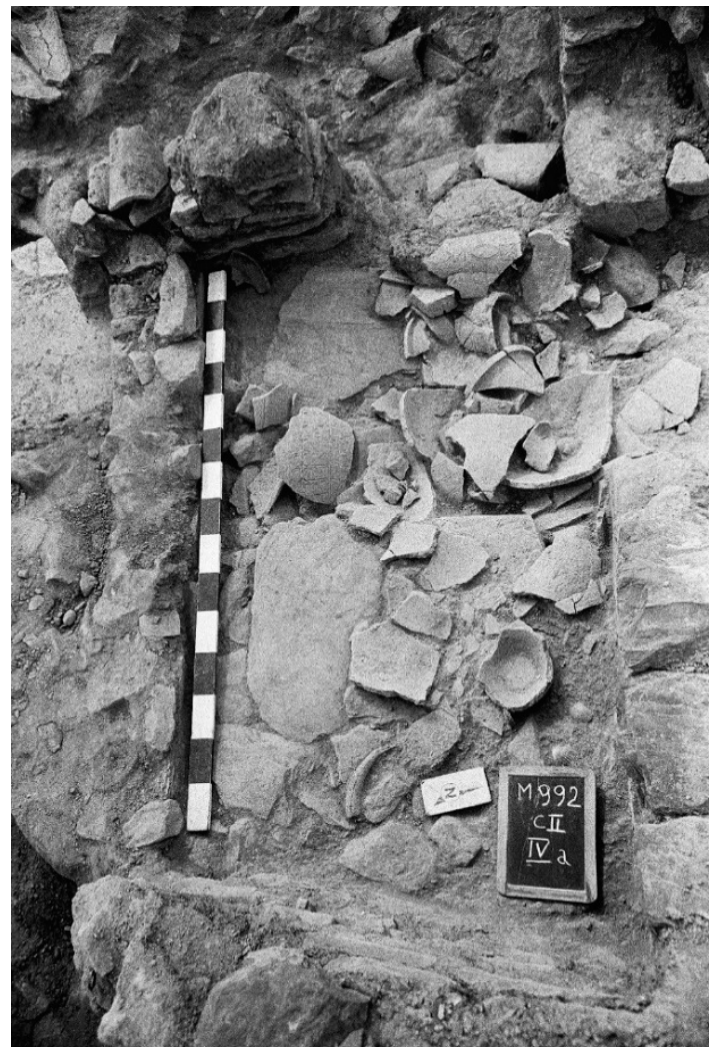

Figure 11. Mértola-house n. 2 (kitchen-exterior compartment). Photo took by author.

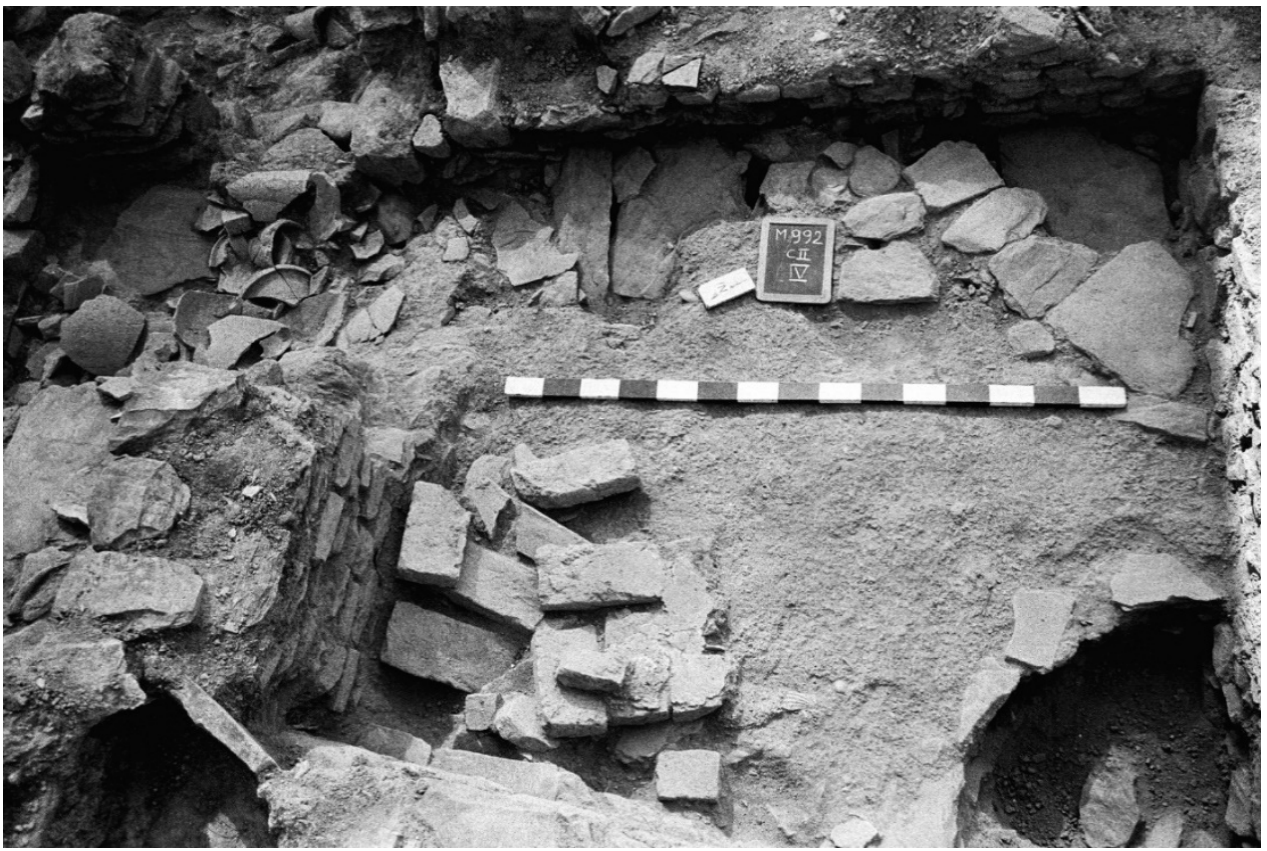

Figure 12. Mértola-house n. 2 (kitchen-hearth place). Photo took by author.

3.6. A Latrine Directly Linked to a Network of Sewers or Covered Ditches Situated on the Exterior of the House

Sanitation systems are of great importance in hot zones like this (Figure 13). An important detail is that, the legislation of the era (the treatises of hisba) advised that Jews or Christians should clean these ditches, on account of this work being unworthy for a Muslim (García Gómez and Évariste 1981, p. 149). 


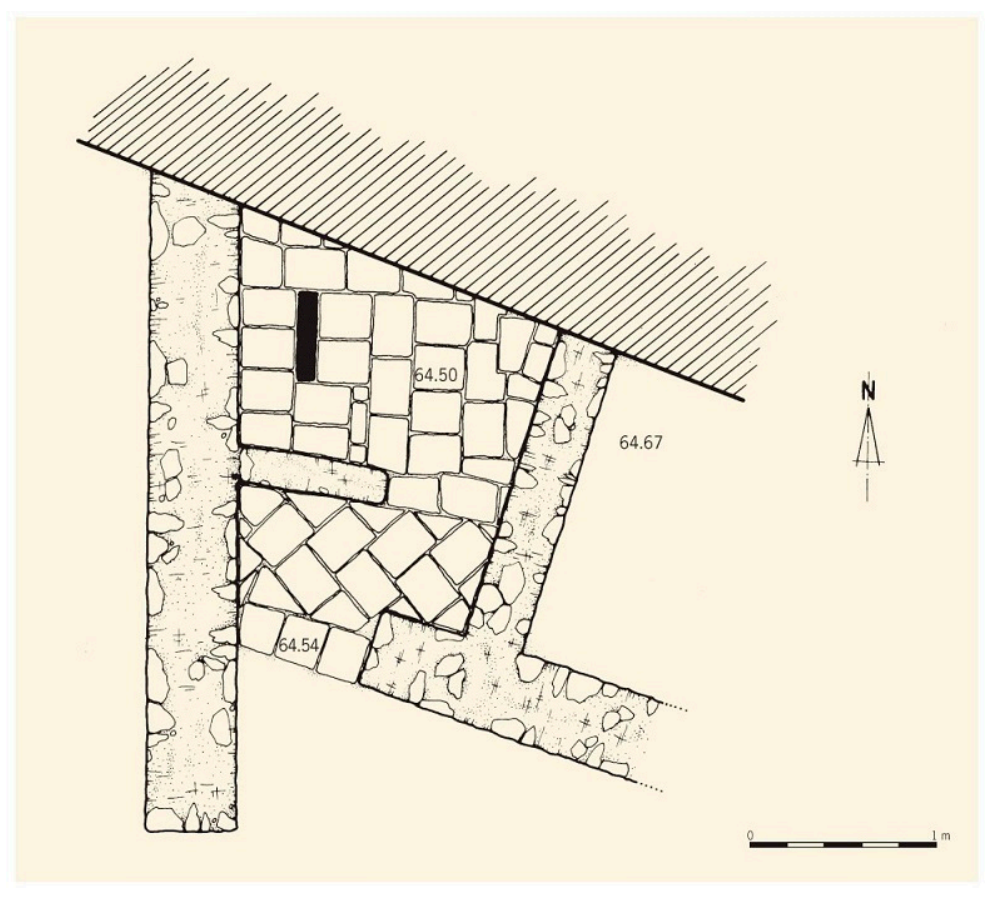

Figure 13. Mértola-house n. 1 (latrine).

It is interesting to note the specificity of function in these houses: a specific use corresponds to each compartment. Evidently of Mediterranean origin, this typology has come to be identified throughout the last few years in all urban excavations carried out in former cities of Andalus (for example; Silves, Saltés, Pechina (Galdeano and Madrid 1990) and Ciesa (Navarro Palazon 1990)). Similar construction techniques were used in all of them. The exterior walls have a stonework foundation, on top of which the walls were built in taipa with a thickness of about half a meter. In some cases, narrow partition walls of adobe (about $20 \mathrm{~cm}$ thick) separated interior compartments. Sometimes multi-coloured decorations were painted over a fine layer of plaster. The floors of the main rooms were painted with red ochre.

The small modular variations recorded here and there do not destroy the image of a model common to all these sites, and that certainly belongs to people of the same social stratum. In spite of a relative specialization of spaces, their polyvalence would confer an undeniable flexibility on these houses.

The "Reconquista", and the new scheme of social organization that is associated with it, appear to have brought an end to this type of house. Although in the south, the Andalusian aulic models have influenced some of the 15th-century and 16th-century palaces, the substitution of this typology for another, more suited to a new family structure of the nuclear type, is evident in a general way. This new structure is defined by the absence of a central patio and a much simpler layout: a one-floor dwelling with two divisions (Conde 1997, p. 245).

The organizational malleability of the urban houses is accentuated in the rural dwellings of the same era. In those, two or three oblong compartments were organized around a broadly quadrangular patio-enclosure. Each one of the spaces, open to the central terrace/yard through a single doorway, had a pronounced polyvalence that repeats organizational schemes present in archaic design-plans of the western Mediterranean (Boone 2009, pp. 146-48).

Contrary to what is noted in relation to the urban dwellings, an extremely conservative type of residence has survived to the present day in the more mountainous zones of the interior of the country. Of probable pre-Roman origin, the continuation of this type of dwelling is also seen in the west of Andalus, in the mountains of Toledo and in the Berber populated zones of the Rif (Boone 1994, Figures 4 and 5). 


\section{Domestic Life}

The most important data concerning the day-to-day life of the houses, identifiable through archaeology, is that related to everyday objects and to eating habits. The investigation is, therefore, limited in a significant way by a lack of written texts.

The identification and study of the eating habits of the population of Mértola in the Islamic period began with the analysis of several batches of animal materials and vegetable macro-remains, gathered in the different parts of the neighbourhood embraced by the archaeological operation, which I oversaw from 1992 to 2005. It is possible, therefore, to date this consumption to the end of the 12th century / first half of the 13th century.

In the first place, it is important to underline the culinary use of meat from different species of animal. It is clear that meat consumption varied according to the ecological conditions of the site and to the financial capacities of the inhabitants of the city. In Mértola, the relative variety of large mammals points to some diversification although, for geographic, economic and cultural reasons, predominance goes to sheep and goats. Another important variable, fundamental to a site like this, consists of the consumption of fish, abundant in the Guadiana River and its tributaries (Macias 2006, pp. 285, 287).

The gastronomy of the period under consideration, both in the case of Mértola and in the south of the region in general, could only be classified as "Arab" or "Islamic" by exaggeration or lack of information. The caliphal court, where traces of clear influence from the Mediterranean east would eventually have been introduced during the consulship of the famous Zyriab (a very influential poet and musician in Abd ar-Rahman II's cohort-789/857 d.C.), which endured for a significant amount of time, is an exception. The native populations demonstrated characteristics that linked them to ancestral traditions that persisted apparently rooted in the daily lives of the population.

This kitchen, that we refer to generically as "Mediterranean", owes much to the Roman tradition and remains very much alive in the south of Portugal. Foods with a high olive oil content and the consumption of garum (fish sauce) normally presented as exclusive to the Roman empire, persisted in the Mediterranean world throughout the whole of the Middle Ages. The garum of ancient Mediterranean tradition persisted many centuries beyond the collapse of the empire, although in Andalus the name might be applied to some small cakes prepared from a base of barley (Bolens 1990, pp. 93-95).

The diet of the Andalusian people was, above all, vegetarian, with cereals in its base (bread, gruel, soups) supplemented by vegetable proteins. Although wheat bread may have been the most valued, many other types of bread existed as substitutes although no archaeological evidence of them remains. One of the most used was rice bread, although it may have had little nutrition. Regarding this last type of bread, opinions are divided. Abu Zahra, cited by Ibn al-Awwam, states rice bread to be the best among the vegetable breads and that it was very nutritious. Another vegetable, the carob, was much used in bread making, a habit that still persists in remote areas of the Algarvian mountains.

The most popular dishes were prepared with a bread base. Harisa, however, was prepared with cereals (although the most appreciated may have been that made with wheat), chopped meat and fat. Seldom enriched with butter or honey, its solid and compact texture was a synonym for quality. It was also common to add milk to this type of gruel, constituting a linking of these two elements-cereals and milk—one of the most important features of Andalusian popular diet. Harisa presents recognizable similarities to the basic process of preparation, with bread crumbs, of one of the most appreciated dishes of popular Alentejan gastronomy.

Tarida (equivalent of açorda [panada]), another much appreciated dish made with a cereal base, was prepared with bread broken into pieces and soaked in a fatty broth, in which previously meat and greens had been cooked. A direct ancestor of the açorda alentejana, tarida was sometimes, and in its poorest version, made only with water, a little olive oil and some condiments. Meat stews, heirs of this tradition, are still today a delicacy particularly appreciated in the south of Portugal where they customarily play a leading role in large family gatherings.

Among the most popular soups would be the gaspacho, a cold soup prepared with bread and chopped vegetables. Not recorded from the archaeological point of view and absent from the cookbooks 
of the Peninsular Islamic period, it should have had a markedly popular character, simply on account of the easy and cheap access of the necessary ingredients.

In relation to vegetables, predominance is given to species archaeologically recorded: the fig, the grape and the chick-pea (Lathyrus cicera) (Macias 2006, p. 284). These species, cited in the Ibn Bassal Treaty, are of the upmost importance (Hernández Bermejo 1990). Even nowadays there is no doubt regarding their relevance in the diet of the lower social classes of Al-Andalus.

Regarding meat, it is possible to understand meat consumption back then through the interpretation of data we currently possess. The presence of lamb is mostly recorded in the southern and inland archaeological sites of the country. It is interesting to note the predominance of bones from the cranium that have been gathered and clearly identified (Macias 2006, p. 285). Two reasons give a particular importance to this finding: on the one hand, because one of the most popular soups in al-Andalus was prepared with the heads of this animal; on the other hand, the persistence, from the dietary point of view, of the consumption of lambs' heads, still today particularly appreciated in the Alentejo region. In the southern regions, it is still customary to consume grilled lambs heads-food usually served in taverns.

Fish made up an important part of the diet of the population of Mértola in the Islamic period. For evident reasons, the fluvial species predominate at the Mértolan table of the Middle Ages. More than $51 \%$ of the specimens we identified in the oldest levels of the archaeological excavation indicated fluvial species: different types of mullet (Mugilidae)-32.2\%, barbel (Barbus) $16.1 \%$ and sturgeon (Acipenser sturio) 3.22\% (Macias 2006, p. 287).

\section{Conclusions}

It is crucial to emphasize the substantial role of archaeology in reconstructing the everyday of the Medieval Islamic past of southern Portugal. Up until the mid-1970s, such a task was not possible to carry out successfully. The archaeological explorations of that time did not-with the exception of the excavations in Cerro da Vila (Algarve)—include the Islamic Period. Mértola and Silves, former capitals of the taifa kingdoms, were the first sites where from 1978 work reached significant dimensions. This was due both to ongoing excavations and subsequent heritage enhancement programmes, as well as to the potential each site possessed. Nowadays, the widespread nature of Islamic archaeology does not enable us to single out any particular excavations. Yet what we may add is that these new dynamics paved the way for the "IV Congresso de Cerâmica Medieval do Mediterrâneo Ocidental", which was held in Lisbon (1987), and the appearance of an archaeology journal (Arqueologia Medieval) in 1992. This boost in the area of Islamic studies also made possible the overview of research in this area, realised in the exhibition "Portugal Islâmico: os últimos sinais do Mediterrâneo", which was open to the public at the Museu Nacional de Arqueologia em 1998 and 1999. Completed investigations, and those in progress, have yielded an appreciable number of master's dissertations and doctoral theses, impossible to enumerate here. However, the work of synthesis done by Christophe Picard on the Gharb stands out, being the most comprehensive and rigorous in its approach.

Funding: This research received no external funding.

Conflicts of Interest: The author declares no conflict of interest.

\section{References}

Bazzana, André. 2005. Excavaciones en la isla de Saltés (Huelva), 1988-2001. Sevilla: Junta de Andalucía/Consejeria de Cultura.

Bedia, J., and André Bazzana. 1994. Saltés y el Suroeste peninsular. In Arqueologia en el entorno del Bajo Guadiana. Huelva: Universidad de Huelva, pp. 619-44.

Bolens, Lucie. 1990. La Cuisine Andalouse. Paris: Albin Michel.

Boone, James. 1994. Rural settlement and islamization in the Lower Alentejo of Portugal. Evidence from Alcaria Longa. In Arqueologia en el entorno del Bajo Guadiana. Huelva: Universidad de Huelva, pp. 527-44. 
Boone, James. 2009. Lost Civilization. The Contested Islamic Past in Spain and Portugal. London: Duckworth.

Catarino, Helena. 2005. Arquitectura de taipa no Algarve islâmico. As escavações nos Castelos de Salir (Loulé) e de Paderne (Albufeira). In Arquitectura de terra em Portugal. Lisboa: Argumentum, pp. 138-43.

Cavaco, Sandra. 2011. O arrabalde da Bela Fria: Contributos para o Estudo da Tavira Islâmica. Master's dissertation, Faculdade de Ciências Humanas e Sociais da Universidade do Algarve, Faro, Portugal.

Coelho, António Borges. 1975. Portugal na Espanha Árabe. Lisboa: Seara Nova, vol. IV.

Conde, Manuel Sílvio. 1997. Sobre a casa urbana no Centro e Sul de Portugal, nos finais da Idade Média. Arqueologia Medieval 5: 243-65.

de Matos, José Luís. 1999. Lisboa Islâmica. Lisboa: Instituto Camões.

Galdeano, Francisco Castillo, and Rafael Martínez Madrid. 1990. La vivienda hispanomusulmana en BayyanaPechina (Almeria). In La Casa Hispano-Musulamana. Aportaciones de la Arqueologia. Granada: Patronato de La Alhambra y Generalife, pp. 111-27.

García Gómez, Emilio, and Lévi-Provençal Évariste. 1981. Sevilla a Comienzos del siglo XII. El tratado de Ibn Abdun. Sevilla: Servicio Municipal de Publicaciones.

Gisbert Santonja, Josep A., Vicent Burguera Sanmateu, and Bolufer I Marques Joaquin. 1992. La Cerámica de Daniya (Dénia)-alfares y Ajuares Domésticos de los Siglos XII-XIII. Valencia: Ministerio de Cultura.

Gomes, Rosa Varela. 2009. O Castelo de Silves-contributos de investigação recente. Xelb 9: 477-88.

Gomes, Ana, and Maria Alexandra Gaspar. 2002. O Castelo de S. Jorge-da fortaleza islâmica à alcáçova cristã. In Mil anos de fortificações na Península Ibérica e no Magreb (500-1500). Actas do Simpósio Internacional Sobre Castelos. Lisbon: Edições Colibri, pp. 397-404.

Gonçalves, Maria José. 2008a. Silves Islâmica: A Muralha do Arrabalde Oriental e a Dinâmica de Ocupação do Espaço Adjacente. Master's dissertation, Faculdade de Ciências Humanas e Sociais da Universidade do Algarve, Faro, Portugal.

Gonçalves, Maria José. 2008b. Silves Islâmica: A Muralha do Arrabalde Oriental e a Dinâmica de Ocupação do Espaço Adjacente. Master's dissertation, Faculdade de Ciências Humanas e Sociais da Universidade do Algarve, Faro, Portugal.

Hernández Bermejo, J. Esteban. 1990. Dificultades en la identificación e interpretación de las espécies vegetales citadas por los autores hispano-árabes. Aplicación a la obra de Ibn Bassal. In Ciencias de la Naturaleza en al-Andalus. Textos y Estudios. Madrid: Editorial CSIC-CSIC Press, pp. 241-63.

Inácio, Isabel, and Helena Catarino. 2009. Ensaio de reconstituição de casas islâmicas do Castelo de Paderne. Xelb 9: 613-22.

Leitão, Maria Isabel Caetano. 2015. A Presença Islâmica em al-Qasr-Uma Análise Sobre o Urbanismo e o Sistema Defensivo. Master's dissertation, Faculdade de Ciências Sociais e Humanas da Universidade Nova de Lisboa, Lisboa, Portugal.

Macias, Santiago. 1996. Mértola. Estudo Histórico-Arqueológico do Bairro da Alcáçova (sécs. XII-VIII). Mértola: Campo Arqueológico de Mértola.

Macias, Santiago. 2006. Mértola. Le Dernier port de la Méditerranée. Mértola: Campo Arqueológico de Mértola, vol. 1.

Macias, Santiago, José Gonçalo Valente, and Vanessa Gaspar. 2016. Castelo de Moura-Escavações Arqueológicas 1989-2013 (Textos). Moura: Câmara Municipal de Moura.

Navarro Palazon, Julio. 1990. La casa Andalusí en Siyasa: Ensayo para una Clasificacion Tipologica. La casa HispanoMusulamana Aportaciones de la Arqueologia. Granada: Patronato de la Alhambra y Generalife, pp. 177-98.

Palma, Maria de Fátima, Miguel Reimão Costa, Susana Gómez Martínez, Virgílio Lopes, and Ana Costa Rosado. 2018. As casas de Mértola: dois mil anos de formas de habitar. Arqueologia Medieval 14: 63-75.

Pereira, Maria Teresa Lopes. 2000. Alcácer do Sal na Idade Média. Lisboa: Ed. Colibri/Câmara Municipal de Alcácer do Sal.

Torres, Cláudio. 1992. O Garb al-Andaluz. In História de Portugal. Lisboa: Círculo de Leitores, vol. I, pp. $363-415$. Vallejo Triano, Antonio. 2013. Madinat Al-Zahra: Historical reality and present-day heritage. In Reflections on Qurtuba in the 21st Century. Madrid: Casa Árabe, pp. 89-109.

(C) 2018 by the author. Licensee MDPI, Basel, Switzerland. This article is an open access article distributed under the terms and conditions of the Creative Commons Attribution (CC BY) license (http:/ / creativecommons.org/licenses/by/4.0/). 